\title{
IMPLEMENTASI UNDANG-UNDANG NOMOR 6 TAHUN 2014 TERHADAP PARTISIPASI MASYARAKAT DALAM PEMBANGUNAN DESA
}

\author{
Samsu Rizal, Nurul Zuriah, Agus Tinus \\ FKIP Universitas Muhammadiyah Malang, Indonesia \\ Email: samsurizal214@gmail.com
}

\begin{abstract}
ABSTRAK
Penelitian ini bertujuan untuk mendeskripsikan: (1) Pelaksanaan Undang-Undang Nomor 6 Tahun 2014 Tentang Desa di Desa Naru Kec. Sape Kab. Bima NTB, (2) Partisipasi masyarakat desa dalam pembangunan desa di Desa Naru Kec. Sape Kab. Bima NTB, (3) Efektitas peran masyarakat dan pemerintahan desa dalam pembangunan desa di Desa Naru Kec. Sape Kab. Bima NTB. Penelitian ini menggunakan penelitian kualitatif dengan pendekatan deskriptif kualitatif. Penelitian dilakukan di Desa Naru Kec. Sape Kab. Bima NTB. Sumber data yang digunakan adalah Kepala Desa Naru dan Tokoh Masyarakat Desa Naru dan menggunakan teknik pengumpulan data wawancara, dokumentasi, observasi. Teknik analisis data yang digunakan adalah reduksi data, penyajian data, dan menarik kesimpulan. Penelitian ini dilakukan di Desa Naru selama dua bulan pada tanggal 10 Juli s/d 17 September 2018. Hasil penelitian menunjukkan: (1) Pelaksanaan Undang-Undang Nomor 6 Tahun 2014 dinilai kurang maksimal dikarenakan pemahaman masyarakat desa mengenai pelaksanaan Undang-Undang Desa ini terbatas; (2) keterlibatan masyarakat desa dalam melakukan pembangunan desa sangat tinggi dengan semangat gotong royong baik partisipasi dalam bentuk tenaga, ide, gagasan maupun materi namun masyarakat desa tidak dapat berpartisipasi secara penuh terkendala kesibukannya mencari nafkah; (3) Pemerintahan desa membuka ruang kepada masyarakat desa agar dapat berperan aktif dalam melakukan pembangunan. Masyarakat dan pemerintahan desa memahami peran, hak, serta kewajibannya dalam melaksanakan pembangunan desa dan adanya transparansi kegiatan antara pemeritahan desa dengan masyarakat desa namun pemerintah desa masih mendominasi dalam melaksanakan pembangunan desa sehingga pelaksanaan pembangunan ada yang tidak sesuai dengan keinginan masyarakat desa karena dinilai tidak sesuai dengan skala prioritas desa.
\end{abstract}

Kata Kunci: Partisipasi Masyarakat Desa; Peran Pemerintah Desa; Pembangunan Desa.

ABSTRACT
This research is aimed to describe: (1) The implemention of law number 6 of 2014 about the village at Naru Village, Sape Sub-Distric, Bima Regency, West Nusa Tenggara; (2) The participant of villagers in the construction of the village at Naru Village, Sape SubDistric, Bima Regency, West Nusa Tenggara; (3) The effectiveness of the people's roles and the local goverment in the construction of the village at Naru Village, Sape Sub-Distric, Bima Regency, West Nusa Tenggara. This research used qualitative research, the design of the study was descriptive design. This research project was carried out in Naru Village, Sape Sub-Distric, Bima Regency, West Nusa Tenggara. The source of data used was a headman and villagers and the data collections used in this research were interview, documentation, and observation. The technique in analyzing the data were data reduction data display and conclusion drawing. This research conducted in Naru Village during two months at July 10th to September 17th,2018. The result of this study showed that: (1) The implementing of law number 6 of 2014 is not queti optimum, because the village society understanding about the implemention of the village law is limited; (2) Involvement of villagers in doing the contruction of the village is higher with their motivation of mutual aid. They are both a energy, idea, opinion, and materialis. However the villagers could not full participated, because they was busy to work; (3) The local government opened the chance for the villagers, so they can have a role in conducting the construction. The villagers and the local government 
understood about their role, right, and obigation in implementing the construction of village. And also, there was the transparency of activity between the local government and villagers. However, the local goverment still dominated in conducting the construction so that the implementation of the construction was not run well based on the villagers' needed because it was not appropriate with priority scale of village.

Keywords: Participation of villagers; Role of Village Government; Village Development

\section{PENDAHULUAN}

Di era otonomi daerah saat ini desa menjadi primadona dalam pemerintahan Joko Widodo-Jusuf Kalla sebagaimana ditunjukkan dalam Nawacita untuk membangun dari pinggiran desa demi menjalankan amanat Undang-Undang dan janji Nawacita tersebut, banyak upaya yang telah dilakukan oleh pemerintahan Jokowi-Jk sejak tahun 2014 hingga sekarang. Upaya yang terbesar diantaranya penyaluran dana desa dan perangkat desa. Pemerintah desa diberikan kewenangan yang lebih luas dalam mengatur dan mengurus kepentingan masyarakat. Pentingnya peraturan desa bertujuan untuk mempercepat terwujudnya kesejahteraan masyarakat melalui peningkatan, pelayanan, pemberdayaan, dan peran serta masyarakat desa, serta meningkatkan daya saing daerah dengan memperhatikan prinsip demokrasi, pemerataan, keadilan, keistimewaan, dan kekhususan suatu daerah dalam sistem Negara Kesatuan Republik Indonesia. Pembangunan yang dulunya dikendalikan oleh pemerintah pusat (sentralistik) mulai bergeser menjadi sistem desentralistik dengan pembangunan yang merata di seluruh Indonesia. Kebijakan desentralisasi di Indonesia pada era reformasi menempatkan masyarakat sebagai pilar utama pemerintahan daerah.

Nurcholis (2011) kedudukan desa sangat penting baik sebagai alat untuk mencapai tujuan pembangunan nasional ataupun sebagai lembaga yang memperkuat struktur pemerintahan negara Indonesia. Desa merupakan ujung tombak pemberian layanan kepada masyarakat, selain itu desa merupakan basis sistem kemasyarakatan bangsa Indonesia yang kokoh sehingga dapat menjadi landasan yang kuat bagi pengembangan politik, ekonomi, sosial-budaya, dan hankam yang stabil dan dinamis. Keikutsertaan masyarakat desa dalam pembangunan desa akan meningkatkan rasa kepedulian masyarakat desa dalam merawat dan menjaga insfrastruktur desa. Partisipasi masyarakat pada setiap program pembangunan desa menjadi kunci suksesnya pembangunan.

Masyarakat desa seharusnya berada pada posisi penting dalam penyusunan pembangunan desa, namun dalam prakteknya masyarakat cenderung diabaikan. Hal ini menyebabkan program-program yang dirancang justru tidak sesuai dengan kebutuhan masyarakat desa. Hal ini dijelaskan oleh (Muluk, 2010) kenyataan dilapangan desentralisasi untuk meningkatkan partisipasi masyarakat tidak sejalan dengan tujuan. Hal ini dikarenakan berbagai persoalan antara lain: (a) adanya dominasi oleh elit lokal; (b) lemahnya kemauan politik pemerintah untuk menjamin partisipasi; (c) lemahnya organisasi kemasyarakatan lokal; dan (d) rendahnya kesadaran masyarakat untuk berpartisipasi. Hal tersebut menunjukkan bahwa sesungguhnya proses pembangunan harus melibatkan masyarakat desa, partisipasi yang dilakukan oleh masyarakat desa dalam pembangunan merupakan pemberdayaan potensi masyarakat melalui musyawarah bertujuan peningkatan penyampaian aspirasi masyarakat desa berupa keinginan dan kebutuhan masyarakat desa sehingga pembangunan desa ditujukan kepada masyarakat desa sehingga mampu mengelola potensi dan sumber daya yang dimiliki desa. 


\section{METODE}

Menurut Zuriah (2009) penelitian deskriptif adalah penelitian yang diarahkan untuk memberikan gejala-gejala, fakta-fakta, atau kejadian-kejadian secara sistematis dan akurat mengenai sifat-sifat populasi atau daerah tertentu. Pendekatan kualitatif dengan maksud untuk menjelaskan dan mengungkapkan fakta yang terjadi di dalam masyarakat. Tujuan yang ingin dicapai dalam penelitian ini adalah mengalisis implementasi Undang-Undang Nomor 6 Tahun 2014 Tentang Desa dan partisipasi masyarakat dalam pembangunan desa di Desa Naru Kec. Sape Kab. Bima NTB. Menurut Moleong (2014) penelitian kualitatif merupakan teori yang dibatasi pengertian, ssuatu pertanyaan, sismatika yang berkaitan dengan seperangkat proporsi yang berasal dari data dan diuji kembali secara empiris. Pendekatan yang digunakan berupa pendekatan deskirptifdengan maksud untuk menjelaskan tentang implementasi Undang-Undang No. 6 Tahun 2014 Tentang Desa Dan partisipasi masyarakat dalam pembangunan desa dengan menganalisis perilaku, persepsi, motivasi, tindakan secara menyeluruh masyarakat Desa Naru. Penelitian ini menyajikan data secara deskriptif dalam bentuk kata-kata dan bahasa. Apa yang dinyatakan oleh informan penelitian mengenai pelaksanaan UndangUndang No. 6 Tahun 2014 dan Partisipasi masyarakat dalam pembangunan desa secara tertulis maupun lisan dipelajari dan diolah sebagai sesuatu yang utuh. Berdasarkan teori diatas peneliti dapat menyimpulkan bahwa penelitian kualitatif yang menggunakan pendekatan deskirptif ialah penelitian yang meneliti tentang suatu pokok permasalahan yang terjadi di suatu lingkungan dengan jalan mendeskirpsikan variabel yang berkenan dengan pokok permasalahan tersebut.

Penelitian ini dilakukan di Desa Naru Kecamatan Sape Kabupaten Bima Provinsi Nusa Tenggara Barat. Desa Naru merupakan lokasi yang dipilih oleh oleh peneliti. Desa ini dipilih sebagai tempat penelitian dikarenakan menjadi ibukota di Kecamatan Sape yang diharapkan dapat menjadi percontohan bagi desadesa yang lainnya. Alasan lain peneliti memilih desa ini dikarenakan Desa Naru menjadi salah satu desa yang sudah mulai pesat perkembangannya dengan didukung fasilitas publik yang memadai seperti kantor kecamatan, pasar, puskesmas, gedung serba guna, lapangan sepakbola kecamatan serta lokasinya yang strategis mudah dijangkau oleh peneliti. Selain itu adanya keterbukaan dari pihak pemerintah desa terhadap penelitian yang akan dilaksanakan oleh peneliti.

Penelitian ini menggunakan teknik pengumpulan data observasi, wawancara, dan dokumentasi. Menurut Sugiyono (2015) teknik pengumpulan data merupakan langkah yang paling strategis dalam penelitian, karena tujuan utama dari penelitian adalah mendapat data, tanpa mengetahui tehnik pengumpulan data, maka peneliti tidak akan mendapat data yang memenuhi standar data yang diterapkan. Tehnik pengumpulan data dapat dilakukan dengan berbagai cara. Dalam penelitian ini, peneliti menggunakan tiga tehnik dalam pengumpulan data penelitian kualitatif meliputi: (1) Metode Wawancara. Menurut Bungin (2010) wawancara adalah proses memperoleh keterangan untuk tujuan penelitian dengan cara tanya jawab sambil bertatap muka antara pewawancara dengan informan. Penelitian ini menggunakan wawancara semiterstruktur dan pihak yang diwawancarai antara lain Kepala Desa untuk mengetahui pelaksanaan Undang-Undang Nomor 6 Tahun 2014 dan keterlibatan masyarakat desa dalam pembangunan Desa, Tokoh Masyarakat Desa untuk mengetahui partisipasi masyarakat Desa dalam melakukan pembangunan desa. (2) Metode Observasi. Menurut Ulfatin (2015) pengamatan atau observasi (observation) yang dilakukan 
ialah untuk mengetahui peristiwa, kejadian, dan perilaku yang diamati secara langsung bagaimana pelaksanaan UU No. 6 Tahun 2014 dan partisipasi masyarakat desa dalam pembangunan desa di Desa Naru Kec. Sape Kab. Bima NTB. (3) Metode Dokumentasi. Menurut Sukmadinata (2007) dokumen merupakan suatu tehnik pengumpulan data dengan menghimpun dan menganalisis dokumen, baik dokumen tertulis, gambar maupun elektronik. Dokumentasi dilakukan dengan cara mengumpulkan dokumentasi pendukung data-data penelitian yang dibutuhkan. Dalam penelitian ini, peneliti menyelidiki benda-benda tertulis seperti catatan, arsip, dokumen pemerintah, peraturan-peraturan, notulen rapat, foto-foto kegiatan, dan sebagainya. Teknik ini digunakan untuk melengkapi data yang diperoleh dari teknik pengumpulan data yang lain. Berdasarkan tehnik pengumpulan data tersebut peneliti menggunakannya untuk mendapatkan informasi dan gambaran tentang pelaksanaan Undang-Undang Nomor 6 Tahun 2014 Tentang Desa dan partisipasi masyarakat desa dalam pembanguna desa Di Desa Naru Kecamatan Sape Kabupaten Bima Provinsi NTB.

Menurut sugiyono

analisis data adalah proses mencari dan menyusun secara sistematis data yang diperoleh dari hasil wawancara, cacatan lapangan, dan dokumentasi dengan cara mengorganisasikan data ke dalam pola, memilih mana yang penting dan yang akan dipelajari, dan membuat kesimpulan sehingga mudah dipahami oleh diri sendiri maupun orang lain. Tehnik analisis data merupakan pemilahan data yang akurat yang dilakukan oleh peneliti. Adapun teknik analisis ini sebagai berikut: (1) Pengumpulan data dilakukan melalui dokumentasi, wawancara dan kuisioner. Data yang telah terkumpul kemudian dibuat arsip dengan menyederhanakan informasi yang terkumpul ke dalam bentuk tulisan agar lebih mudah dipahami. Data yang terkumpul dipilih sesuai dengan fokus penelitian dan diberi kode untuk memudahkan peneliti dalam mengkategorikan data-data tersebut. (2) Reduksi data merupakan salah satu kegiatan berupa merangkum dan menafsirkan data untuk memperoleh gambaran tentang pelaksanaan Undang-Undang Nomor 6 Tahun 2014 Tentang Desa dan partisipasi masyarakat dalam pembangunan desa sehingga data yang diperoleh lebih jelas. Pencacatan harus jelas dan benar-benar teliti. Data yang direduksi harus disusun secara sistematis dan mengambil halhal yang diperlukan. (3) Penyajian Data untuk melakukan penyajian, peneliti dapat menguraikan dalam bentuk bagan, seperti diuraikan dalam bentuk sesame jenisnya. Penyajian data yang digunakan oleh peniliti berupa deskrripsi. Deskirpsi data digunakan untuk memperjelas informasi yang diperoleh. (4) Penarikan Kesimpulan. Peneliti menarik kesimpulan dari hasil analisis data yang sudah dilakukan. Penarikan kesimpulan ini bertujuan untuk menjawab semua rumusan masalah yang telah dirumuskan sejak awal. Kesimpulan ini diharapkan menjadi temuan baru yang sebelumnya masih belum jelas sehingga setelah diteliti dapat menjadi lebih jelas dalam kaitannya mengembangkan tata pemerintahan yang baik di lingkup desa. Kesimpulan yang dikemukakan apabila sudah menghasilkan bukti-bukti yang kuat dan bisa mendukung kesimpulan tersebut, dan jika buktinya kurang akurat maka peneliti kembali ke lapangan untuk mengumpulkan data yang kridibel.

\section{HASIL DAN PEMBAHASAN}

Pembahasan berisi tentang hasil penelitian yang dibahas oleh peneliti. Pembahasan akan dibagi menjadi tiga yaitu: (1) Pelaksanaan UU No. 6 Tahun 2014 tentang desa di Desa Naru; (2) Partisipasi masyarakat dalam pembangunan desa; 
(3) Efektifitas peran masyarakat dan pemerintah desa dalam pembangunan desa.

Pelaksanaan Undang-Undang Nomor 6 Tahun 2014 Tentang Desa di Desa Naru Kec. Sape Kab. Bima NTB

Penerapan dari Undang-Undang Nomor 6 Tahun 2014 Tentang Desa penggunaannya akan berdampak secara langsung bagi kehidupan masyarakat, serta dengan adanya kucuran dana yang sangat besar yang diperuntukkan untuk desa dan memberikan ruang bagi pemerintahan desa dalam mengelola sistem pemerintahan tanpa adanya intervensi dari pemerintah daerah hal ini sejalan dengan pengaturan desa yang terdapat dalam Undang-Undang Nomor 6 Tahun 2014 menjadikan desa mampu mengelola pemerintahan desanya secara mandiri, kuat, sejahtera, dan mampu menanggulangi kemiskinan masyarakat desa. Pernyataan bapak Ilham selaku kepala Desa Naru bahwa Desa Naru sudah menerapkan Undang-Undang Nomor 6 Tahun 2014 Tentang Desa, pemerintah Desa Naru sudah menerapkan UndangUndang Nomor 6 Tahun 2014 sebagai pedoman pelaksanaan penyelenggaraan pemerintahan desa di Desa Naru.

Undang-Undang Nomor 6 Tahun 2014 Tentang Desa menjadikan masyarakat desa sebagai subjek pembangunan tujuannya adalah menumbuhkan cinta tanah air yang mempunyai rasa tanggung jawab terutama dalam merawat, melindungi, menjaga fasilitas desa yang telah dibangun secara bersama. Pengetahuan masyarakat desa mengenai Undang-Undang Nomor 6 Tahun 2014 Tentang Desa berdasarkan hasil dari observasi dan interview peneliti dengan beberapa masyarakat Desa Naru menunjukkan dapat dikatakan kurang/ minim sekali hal ini dipengaruhi oleh tingkat SDM dari masyarakat desa karena rata-rata pendidikan hanya sampai pada tingkat Sekolah Menengah Atas (SMA) dan kebanyakan banyak yang tidak bersekolah disisi lain kesibukan masyarakat Desa Naru yang bermayoritas berprofesi sebagai petani membuat mereka untuk pergi setiap hari dari pagi sampai sore hari berpengaruh pada keingintahuan masyarakat desa terhadap Undang-Undang Nomor 6 Tahun 2014 Tentang Desa sehingga kurangnya waktu yang dimiliki oleh masyarakat desa berdampak pada partisipasi yang dilakukan oleh masyarakat desa. Berdasarkan hasil wawancara kepada kepala desa naru menunjukkan bahwa pemahaman terhadap pelaksanaan Undang-Undang Nomor 6 Tahun 2014 Tentang Desa masih sangat minim sehingga perlu adanya pendampingan dari Pemerintahan Kabupaten secara instens dan menjalin komunikasi sesering mungkin dengan aparatur desa yang lain, camat, dan dengan pemerintah Kabupaten Bima dibutuhkan perbaikan agar potensi yang ada dapat dikelola secara maksimal sehingga upaya peningkatan kesejahteraan hidup masyarakat Desa Naru dapat tercapai secara maksimal. Diperlukan juga mengenai kesiapan aparatur desa dengan pemahaman yang maksimal sehingga Undang-Undang Nomor 6 Tahun 2014 dapat terealisasi dengan baik. Observasi yang dilakukan oleh peneliti secara langsung dilapangan untuk mengetahui pelaksanaan Undang-Undang Nomor 6 Tahun 2014 dan partisipasi masyarakat terhadap pembangunan desa. Berdasarkan observasi yang dilakukan oleh peneliti selama berada di tempat penelitian bahwa masyarakat desa belum sepenuhnya memahami mengenai Undang-Undang Nomor 6 Tahun 2014 Tentang Desa. Masyarakat diharapkan selalu berpartisipasi secara aktif baik dalam memahami penerapan UndangUndang Nomor 6 Tahun 2014 maupun dalam melakukan partisipasi pembangunan desa yang berlangsung agar pembangunan berjalan sesuai dengan harapan dan kebutuhan masyarakat desa. Selama ini masyarakat desa hanya memahami mengenai dana desa 
yang besar dari Undang-Undang Nomor 6 Tahun 2014 sebanyak 1 M (satu miliyar), masyarakat Desa Naru hanya merasakan dampak dari dana tersebut terhadap pembangunan desa.

Berdasarkan hasil penelitian yang telah dilakukan oleh peneliti maka ditemukan bahwa dalam pelaksanaan Undang-Undang Nomor 6 Tahun 2014 antara lain: Masyarakat Desa Naru masih acuh tak acuh dalam penerapan UndangUndang Desa Nomor 6 tahun 2014 hal itu dilihat dari pemahaman masyarakat desa hanya mengenai alokasi dana yang besar untuk tiap desa yang mencapai 1 Miliyar perdesa.

\section{Partisipasi masyarakat dalam pembangunan di Desa Naru Kec. Sape Kab. Bima NTB}

Partisipasi masyarakat merupakan wujud kepedulian masyarakat terhadap pembangunan desanya. Peran serta masyarakat sangat penting karena masyarakat merupakan pihak yang paling mengetahui keadaan di daerahnya, namun pemerintah desa juga memiliki kebijakan tersendiri dalam memberikan kesempatan masyarakat untuk dapat berpartisipasi. Upaya pembangunan wilayah pedesaan dengan mendorong partisipasi yang dilakukan oleh masyarakat Desa Naru dalam pembangunan desa sebagai wujud kedaulatan masyarakat desa dalam meningkatkan kesejahteraan hidup, perekonomian desa. Ditandai dengan keterlibatan masyarakat desa dalam kegiatankegiatanpembangunandesayang dilaksanakan oleh pemerintah desa, masyarakat desa yang memiliki peran sangat penting dalam kelancaran proses pembangunan desa. Dengan adanya proses pembangunan desa dapat dilihat seberapa besar kecintaan dan keinginan masyarakat desa dalam kemajuan desa serta kesejahteraan hidup masyarakat desa. Hasil wawancara kepada kepala Desa Naru menunjukkan bahwa partisipasi yang dilakukan oleh masyarakat Desa Naru dalam bentuk tenaga dengan sistem gotong royong menentukan efesiensi waktu yang lebih cepat dalam peaksanakan pengerjaan pembangunan tersebut. Dalam pelaksanan pembangunan, pemerintah Desa Naru melibatkan masyarakat desa dengan membaginya dalam beberapa tim dengan semangat gotong royong. Hasil dari pelaksanaan pembangunan bisa dipantau langsung oleh masyarakat dan masyarakat desa dapat langsung berpatisipasi secara langsung baik berupa materi, tenaga dan berupa makanan/minuman kepada pekerja. Pada awal bulan September dilaksanakan pembangunan jembatan di dusun kore. Masing-masing masyarakat desa khususnya masyarakat Dusun Kore meluangkan waktu dan tenaganya untuk berpartisipasi secara langsung dalam proses pengerjaan pembangunan jembatan. Hal ini sejalan dengan hasil dokumentasi yang telah dilakukan oleh peneliti sebagai berikut:
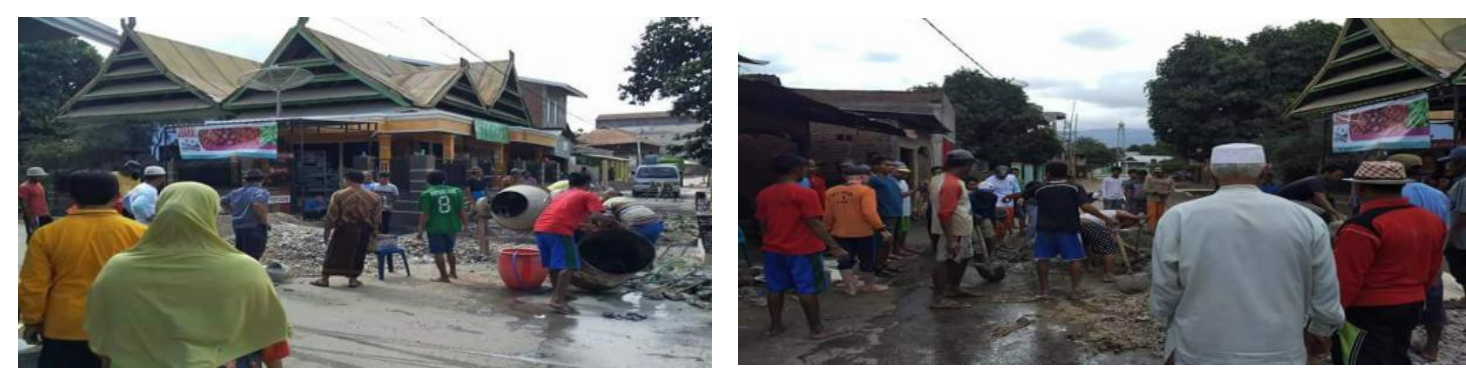

Gambar 1: Gotong royong masyarakat Desa Naru dalam pembangunan jembatan di dusun kore Desa Naru. 
Foto dokumentasi tersebut menunjukkan pelaksaan pembangunan dengan adanya partisipasi yang dilakukan oleh masyarakat desa dalam bentuk tenaga dengan sistem kerja gotong royong. Proses partisipasi masyarakat dilakukan oleh beberapa warga desa khususnya pemuda desa yang melakukan partisipasi dalam program pembangunan jembatan berbentuk tenaga. Hal ini dikarenakan masyarakat desa secara luas yang bermayoritas berprofesi sebagai petani memiliki waktu yang terbatas dalam memberikan partisipasi secara langsung disisi lain pemerintah desa juga memiliki kebijakan tersendiri dalam memberikan kesempatan bagi masyarakat desa untuk dapat berpartisipasi. Partisipasi masyarakat dapat diartikan sebagai bentuk keikutsertaan masyarakat dalam proses pengidentifikasian masalah dan potensi yang ada di masyarakat, pemilihan dan pengambilan keputusan tentang alternative solusi untuk menangani masalah, pelaksanaan upaya menangani masalah, dan keterlibatan masyarakat dalam proses mengevaluasi perubahan yang terjadi (Adi, 2007: 27).

Berdasarkan penelitian yang telah dilakukan oleh peneliti maka ditemukan bahwa partisipasi masyarakat dalam pelaksanaan program pembangunan desa antara lain: Kesadaran masyarakat Desa Naru memiliki semangat gotong royong dan kesadaran diri untuk terlibat dalam pelaksanaan program pembangunan desa walaupun terkendala masalah waktu dan keadaan mengenai kesibukan masyarakat desa dalam mencari nafkah. Pelaksanaan program pembangunan desa, pemerintah desa selalu melibatkan partisipasi masyarakat baik itu berupa tenaga, pikiran ide dan gagasan, maupun uang terutama terkait program pembangunan desa.

Partisipasi masyarakat dalam program pembangunan desa diharapkan tidak sebatas tenaga dan menyesuaikan dengan keinginan pemerintah desa tapi lebih berkembang pada tahap opini, pemikiran, tenaga, keterlibatan langsung dari kegiatan yang dilaksanakan, melalui pengawasan terutama mengenai penggunaan anggaran dana desa, menjaga dan merawat infrasturuktur yang telah dibangun serta peka terhadap segala bentuk informasi yang telah disediakan maupun yang disampaikan oleh pemerintah desa. Hal ini berdampak pada pelaksanaan program pembangunan yang telah maupun yang akan dijalankan oleh pemerintah desa.

\section{Efektifitas peran masyarakat dan pemerintahan desa dalam pembangunan di Desa Naru Kec. Sape Kab. Bima NTB}

Salah satu hal mendasar yang mucul berkaitan dengan peran serta masyarakat dalam pelaksanaan pembangunan desa adalah mengenai seberapa jauh pemerintah mempunyai kewenangan dalam melakukan pembangunan desa dan seberapa jauh masyarakat desa memiliki peran didalamnya. Masyarakat dan pemerintah desa merupakan salah satu komponen satu kesatuan yang berperan aktif dalam melakukan pembangunan desa, dengan semakin berkembangnya pemahaman masyarakat dan pemerintahan desa kebutuhan pembangunan desa. Masyarakat desa merupakan objek vital dari pembangunan desa yang diatur dalam perundangundangan dibidang pembangunan desa, khususnya dalam konteks peran, hak, serta kewajibannya. Sedangkan pemerintah desa memberi ruang kepada masyarakat desa agar dapat berperan aktif dalam melakukan kontribusi dalam melakukan pembangunan dan pemerintah desa juga sebagai penyedia anggaran dalam melakukan pembangunan agar pembangunan desa berjalan efektif, efisien.

Kedudukan pemerintah desa awalnya sebagai pelaku dalam pembangunan mulai tahap perencanaan, pelaksanaan, sampai tahap evaluasi, berubah menjadi pola penyelenggara pelayanan dan fungsi 
pemerintah desa tidak lagi menjadi dominasi. Peran pemerintah desa di Desa Naru dalam pelaksanaan pembangunan adalah sebagai koordinator dalam pembangunan desa. Selain itu pemerintah desa juga sebagai fasilitator yang menjembatani berbagai kepentingan masyarakat desa. Misalnya untuk berbagai usulan dari masyarakat desa akan ditampung kemudian ditentukan skala prioritasnya mana yang perlu untuk dicarikan solusinya. Pemerintah Desa Naru membenarkan bahwa dalam setiap perencanaan maupun pelaksanaan pembangunan desa selalu melibatkan masyarakat desa, tokoh masyarakat desa, karang taruna, rt/rw. Berdasarkan pada penuturan bapak Ilham program pembangunan sekarang berbeda dengan program pembangunan terdahulu. Dahulu memang yang menentukan dan melaksanakan pembangunan adalah pemerintah saja sedangkan masyarakat hanya diam dan tinggal merasakan hasil dari pembangunan tersebut. Namun sekarang berbeda, masyarakat sendirilah yang berperan aktif dalam pelaksanaan pembangunan desa sementara pemerintah desa memfasilitasi dan mengkoordinir pelaksanaan pembangunan desa secara efektif dan efisien sehingga pembangunan yang dilaksanakan benarbenar bermanfaat bagi masyarakat desa.

Partisipasi memberikan kesempatan kepada masyarakat untuk memecahkan berbagai persoalan yang muncul didesanya. Pelaksanaan pembangunan dilaksanakan oleh pemerintah desa dan masyarakat desa akan membuat pembangunan berjalan secara efektif dan terarah. Salah satu faktor pendukung kerjasama pemerintah masyarakat desa dalam pembangunan desa adalah masyarakat desa harus memahami posisi dan perannya sedangkan pemerintah desa menjadi penentu terjadinya kerjasama yang baik antara pemerintah desa dengan masyarakat desa. Pemerintah desa harus mampu mendorong masyarakat desa untuk ikut serta berperan aktif dalam pembangunan desa, dorongan ini tidak hanya berupa ajakan maupun seruan-seruan semata akan tetapi pemerintah memberikan contoh yang baik kepada masyarakat sehingga masyarakat bergerak dan meniru apa yang dilakukan oleh pemerintah desa dan akhirnya masyarakat memahami peran dan posisinya.

Dari penjelasan Bapak Ilham dapat diketahui bahwa selain melalukan sosialisasi sebagai upaya pendekatan dan memberikan informasi kepada masyarakat desa, pemerintah desa juga memberikan teladan langsung dengan turun langsung kelapangan misalnya ikut kerja bareng masyarakat desa dalam kerja bakti, rabat gang, pembuatan salur irigasi hal ini diharapkan membuat masyarakat desa nyaman dan berperan secara sukarela. Salah satu penghambat dalam kerjasama antara pemerintah desa dan masyarakat desa dalam pelaksanaan pembangunan biasanya muncul pada tahap perencaan dan tahap pelaksaan pada tahap proses pembangunan desa. Pada tahap perencanaan biasanya akan muncul pihak yang setuju yang tidak setuju terutama dalam hal menentukan prioritas pembangunan desa takutnya menjadi provakot ditengah masyarakat desa sedangkan untuk dalam proses pelaksanaan pembangunan diakibatkan oleh kesibukan masyarakat desa dalam mencari nafkah sehingga menyebabkan pelaksanaan pembangunan desa tersendat ataupun mengalami kendala.

Berdasarkan penelitian yang telah dilakukan oleh peneliti maka ditemukan bahwa efektifitas peran masyarakat dan pemerintahan desa dalam pembangunan di desa antara lain:

Pertama, pemerintah desa membuka ruang kepada masyarakat desa agar dapat berperan aktif dalam pembangunan desa dan melakukan koordinasi kepada masyarakat desa melalui ketua rt, tokoh masyarakat. Pemerintah Desa Naru berusaha menjadi teladan yang baik hal ini 
dilihat di lapangan bahwa pemerintah Desa Naru turun langsung melakukan kerja bakti bersama masyarakat desa.

Kedua, masyarakat desa berusaha berperan aktif dalam melaksanakan pembangunan hal ini dilihat dari keikutsertaan masyarakat desa dalam melaksanakan proses pembangunan desa, menyumbang ide, fikiran, gagasan, kritikan walaupun terkendala keadaan dan waktu.

Ketiga, dalam pelaksanaan pembangunan desa di Desa Narumengalami faktor hambatan dan faktor pendukung dari peran masyarakat desa dan peran pemerintah desa. Untuk faktor pendukung dari peran pemerintah desa melakukan transparasansi ataupun keterbukaan pada rincian kegiatan yang dilaksanakan oleh pemerintah desa dan pemerintah desa melakukan pendekatan yang baik kepada masyarakat desa sehingga tidak tercipta jarakantara pemerintah desa dan masyarakat desa sehingga dalam tahap pembangunan desa menjadi efektif dan efisien, untuk faktor pendukung dari peran masyarakat desa sendiri memahami peran dan hak serta kewajibannya dalam melakukan pembangunan desa terutama dalam hal pelaksanaan pembangunan dilapangan dengan berbagai keahlian masyarakat sangat membantu proses pelaksanaan pembangunan desa. Sedangkan untuk faktor penghambatnya dari peran masyarakat desa yaitu masyarakat tidak bisa berperan secara penuh dalam pelaksaan pembangunan desa terkendala waktu dan keadaan dimana masyarakat desa mencari nafkah dan ada juga masyarakat desa yang menginginkan dilaksanakannya pembangunan yang tidak sesua dengan skala prioritas, untuk peran pemerintah sendiri masih mendominasi dalam pelaksanaan pembangunan desa.

\section{SIMPULAN}

Pelaksaan Undang-Undang Nomor 6 Tahun 2014 di Desa Naru tidak diterapkan secara maksimal diakibatkan oleh beberapa faktor: pertama, masyarakat Desa Naru rata-rata berpendidikan tamatan SMA dan kebanyakan yang tidak sekolah serta masyarakat Desa Naru yang sibuk dalam mencari nafkah kesawah/lading karena kebanyakan berprofesi sebagai petani.

Partisipasi masyarakat di Desa Naru dalam pembangunan desa kurang berjalan optimal karena masyarakat luas desa tidak dapat melibatkan diri di akibatkan kendala waktu dan keadaan sehingga partisipasi masyarakat desa tidak dilakukan secara penuh dan maksimal. Keterlibatan masyarakat desa dalam berpartisipasi yang dilakukan hanya berbentuk tenaga, pemberian makanan dan minuman terhadap para pekerja pembangunan desa, padahal masyarakat desa merupakan subjek pembangunan, masyarakat desa adalah komponen utama yang harus dilibatkan dalam pembangunan, karena kebutuhan kepentingan dan harapan masyarakat desa menjadi sesuai dan terarah.

Hubungan pemerintah dan masyarakat desa sangat baik. Pemerintah desa berperan mengkoordinasi, memfasilitasi masyarakat desa untuk dapat berperan aktif dalam pembangunan desa serta menyuplai dana dalam terlaksananya pembangunan desa sehingga membentuk kesadaran masyarakat desa berkontribusi dalampembangunan desa. Sedangkan untuk peran masyarakat ikut terlibat dalam tahap perencanaan hingga ke pelaksanaan proses pembangunan desa. Dalam pelaksanaannya terdapat faktor pendukung dan penghambat dari peran pemerintah desa dan masyarakat desa, untuk faktor pendukungnya yaitu adanya kesadaran masyarakat mengenai peran, hak, serta kewajibannya dalam melakukan pembangunan desa sedangkan untuk faktor penghambatnya sendiri yaitu tingkat kesadaran masyarakat desa yang masih rendah serta pemerintah desa lebih mendominasi dalam pelaksanaan pembangunan desa. 
DAFTAR PUSTAKA

Adi, Isbandi Rukminto. 2007. Perencanaan Partisipatoris Berbasis Aset Komunitas: dari Pemikiran Menuju Penerapan. Depok: FISIP UI Press.

Astuti, Dwi. 2014. Persepsi Masyarakat Terhadap Pelaksanaan UU Nomor 6 Tahun 2014 Tentang Desa Di Desa Bumiayu Pati. Demokratia, 2 (1)

Bungin, Burhan. 2009. Metodologi Penelitian Kuantitatif: Komunikasi, Ekonomi, Kebijakan Publik Serta Ilmu-ilmu Sosial Lainnya (Cetakan 4). Jakarta: Kencana.

Bungkaes, Heri Risal; Posumah, J.H; dan Kiyai, Burhanuddin. 2013. Hubungan Efektifitas Pengelolaan Program Raskin Dengan Peningkatan Kesejahteraan Masyarakat Di Desa Mamahan Kecamatan Gemeh Kabupaten Kepualauan. Acta Diurna Komunikasi. 2 (2) 1-23.

Letsoin, Hendro. 2016. Partisipasi Masyarakat Dalam Pelaksanaan Pembangunan Di Desa Coa Distrik Kaimana Kabupaten Kaimana. Jurnal Politico, 4 (1) 1-12.

Moeleong, Lexy, J. 2014. Metodologi Penelitian Kualitatif (Edisi Revisi). Bandung: Remaja Rosdakarya.

Mondong, Hendra. 2013. Peran Pemerintah Desa Dalam Meningkatkan Partisipasi Masyrakat Dalam Pembangunan Desa. Governance. 5 (1) 1-18.

Muluk, M.R Kahairul. 2010. Menggugat Partisipasi Publik dalam Pemerintahan Daerah (Sebuah Kajian dengan Pendekatan Berpikir Sistem) (Cetakan 2). Malang: Banyumedia Publishing.
Nurcholis, Hanif. 2011. Pertumbuhan dan Penyelenggaraan Pemerintahan Desa. Jakarta: Erlangga.

Nurcholis, Hanif. 2013. Undang-Undang Nomor 6 Tahun 2014 Tentang Desa Dilihat Dari Pasal 18 B Ayat 2 UUD 1945. Makalah ini diangkat dari peneltian Hibah Bersaing Ditjen Dikti Kemendikbud 20122013 yang dipresentasikan dalam 2013 International Conference On Public Administration: Public Sector Reform \& Government In Transition: Values, Leadership, Institutions, Citizen Engagement \& Human Rights, Philippines, Oktober 1-2, 2013. Dalam Program Pasca Sarjana, (Online), (http://www.unter) dalam 20 Januari 2019

Sagai, Fandy V. 2015. Peran Peemerintah

Desa Dalam Pembangunan Infrastruktur. Jurnal Eksekutif. 1 (4)

Sugiyono, 2015. Metode Penelitian Pendidikan: Pendekatan Kuantitatif, Kualitatif, dan R\&D. Bandung: Alfabeta.

Sukmadinata, Syaodih, Nana. 2007. Metode Penelitian Pendidikan. Bandung: Remaja Rosdakarya.

Ulfatin, Nurul. 2015. Metode Penelitian Kualitatif Di Bidang Pendidikan: Teori Dan Aplikasinya: Studi Kasus Etnografi, Interaksi, Simbolik, dan Penelitian Tindakan Pad Konteks Manajemen Pendidikan. Malang: Media Nusa Creative

Zuriah, N. 2009. Metodologi penelitian Sosial dan Pendidikan. Jakarta: PT. Bumi Aksara. 